\title{
Internal Versus External Equity Funding Sources and Earnings Response Coefficients
}

\author{
Chul W. Park \\ Assistant Professor of Accounting \\ School of Business and Management \\ Hong Kong University of Science and Technology \\ Clearwater Bay, Kowloon, Hong Kong \\ E-Mail: acparkc@ust.hk \\ and

Morton Pincus* $^{*}$
Associate Professor of Accounting
Tippie College of Business
The University of Iowa
108 PBAB
Iowa City, IA 52242-1000, U.S.A.
319/335-0915
E-mail: morton-pincus@uiowa.edu

Current version: March 2000

* Corresponding author.

We thank the anonymous referee and Tim Loughran, Eric Noreen, Charlie Wasley, Ben Wilner, and T. J. Wong for their helpful comments. 


\title{
Internal Versus External Equity Funding Sources and Earnings Response Coefficients
}

\begin{abstract}
Because of transactions costs and investor/manager information asymmetries, internally generated funds should be less costly than funds raised by issuing shares. This suggests that as firms use more internal funds relative to external equity, their costs of equity capital will fall and the rate the market uses to discount unexpected earnings of such firms will be lower. We hypothesize that (1) firms having a higher proportion of internal to external equity will have larger earnings response coefficients, and (2) this effect will be magnified for high growth firms since the disparity between inside information and publicly available information about high growth firms' investment opportunities is greatest. We find support for both hypotheses using pooled and annual cross-sectional regressions after controlling for other determinants of ERCs. The results are also generally robust to alternative measures of the mix of equity funding sources and of unexpected earnings and to consideration of other factors affecting the mix of equity capital.
\end{abstract}




\section{Internal Versus External Equity Funding Sources and Earnings Response Coefficients}

\section{Introduction and Theoretical Development}

Research examining the relation between earnings and share prices often focuses on the earnings response coefficient since the ERC captures the sensitivity of security returns to unexpected earnings. Accounting researchers have identified a number of determinants of ERCs, including earnings persistence, growth opportunities, riskiness of earnings, auditor quality, and firm size (e.g., Kormendi and Lipe (1987), Collins and Kothari (1989), Easton and Zmijewski (1989), Teoh and Wong (1993)). In this paper, we hypothesize and provide support for another determinant of ERCs; namely, the mix of internally and externally generated equity capital.

The finance literature documents that firms exhibit a clear preference for internal funds (i.e., retained earnings) over external sources of financing such as debt or issuing shares (e.g., Brealey and Myers (1984), Brealey and Myers (1996), James and Wier (1988), Pinegar and Wilbricht (1989)). ${ }^{1}$ Various explanations have been postulated for this preference for internal funding. First, using internal funds provides managers with greater flexibility. For example, managers can more quickly finance and thus implement investment plans, and they retain the option of raising funds externally in the future. Second, firms avoid costs such as legal, accounting, and underwriting fees when using internal funds, but they must incur such flotation costs when raising funds externally (e.g., Smith (1977)). Third, because there is asymmetric information between managers and investors about a firm's investment opportunities, the market may undervalue a firm's new shares relative to the value that would be assessed if managers' information about their firm's investment plans were publicly available (see Myers and Majluf (1984), 
Myers (1984)). ${ }^{2}$ Consistent with this argument, the stock market generally responds negatively to announcements of the issuance of common shares (e.g., Smith (1986)).

To avoid the costs of potential delays in implementing projects as well as flotation and information asymmetry costs, firms can retain sufficient funds internally to be used for economically worthwhile investments. This is referred to as "financial slack" (e.g., Brealey and Myers (1996)). The greater the level of financial slack a firm has, the less dependent it is on the external market for funds. ${ }^{3}$

Our discussion suggests that the cost of internal equity generally is lower than the cost of external equity. This has implications for the traditional ERC literature. Models of the relation between excess security returns and unexpected earnings typically assume a frictionless and perfect capital market, which implies that capital structure is irrelevant to firm valuation (Modigliani and Miller (1958)). ${ }^{4}$ Consequently, ERC models discount unexpected earnings using a single cost of equity capital, irrespective of the sources of equity capital. ${ }^{5}$ However, in the presence of transaction costs and manager/investor information asymmetries, different sources of equity financing have different costs, and thus the mix of internally and externally generated equity can affect ERCs through a composite discount rate that reflects these alternative sources.

It is well accepted in finance (e.g., Weston and Brigham (1982), Brealey and Myers (1996)) that the weighted-average cost of capital is a simple and intuitively appealing discount rate when both debt and equity are the sources of funds. Similarly, we use a weighted-average cost of equity capital to approximate the discount rate that reflects the mix of internal and external equity capital. That is,

$$
r=[I /(I+E)] \times r_{i}+[E /(I+E)] \times r_{e}
$$

where

$$
\mathrm{r}=\text { weighted-average cost of equity capital; }
$$


$\mathrm{I}=$ total internal funds used to generate earnings;

$\mathrm{E}=$ total external funds used to generate earnings;

$r_{i}=$ cost of internal equity funds when all equity funds are from internal equity financing;

$\mathrm{r}_{\mathrm{e}}=$ cost of external equity funds when all equity funds are from external equity financing.

Equation (1) indicates that if the cost of internal funds is less than the cost of external equity, then as the use of internal financing increases relative to the use of external equity, the discount rate applied to unexpected earnings will fall. ${ }^{6}$ This will result in higher ERCs. Further, this has implications for high growth versus low growth firms.

We expect that the degree of manager/investor information asymmetry about investment opportunities will be greater for high growth firms vis-à-vis low growth firms. Information about high growth investment opportunities must remain proprietary for some period of time since its premature public disclosure would help competitors and thus reduce the value of the firm (Myers and Majluf (1984)). Accordingly, we expect that high growth firms will tend to withhold information from the investors about their portfolios of positive net present value projects to reduce this information cost. Furthermore, given the high cost of revealing private information about investment prospects, information about growth opportunities is more costly to verify and convey to the market than is information about assets in place (Barth et al. 1999)). Hence, if manager/investor information asymmetry about investment opportunities is greater for high growth firms, their cost of external equity will be higher. In turn, the impact of internal relative to external equity financing should be greater for high growth firms as compared to low growth firms. ${ }^{7}$

Our analysis leads to the following testable hypotheses. First, ceteris paribus, ERCs are positively associated with ratios of internal to external equity. Second, ceteris paribus, ERCs of high 
growth firms are more sensitive to the ratio of internal to external equity than are the ERCs of low growth firms.

We should note that the choice of internal versus external financing is endogenous. One example of this is prior profitability. Firms that tend to use more internal financing may have been relatively successful in generating cash from operations, and thus have more funds available internally. To the extent that historical profitability is indicative of future profitability, prior profitability rather than the equity mix may explain our results. To explore this possibility, we will examine whether prior profitability, as opposed to the mix of equity financing, is the factor that explains the magnitude of ERCs. Another endogenous factor is the extent of managerial ownership of stock. The more shares managers hold in their firms, the more likely it is that they are reluctant to dilute their equity claims by issuing new shares. Such firms would have a higher proportion of internal to external sources of equity funding, but the equity mix should not have implications for the discounting of unexpected earnings. In this case, there would be no relation between ERCs and the equity mix. ${ }^{8}$ We will consider the degree of managerial ownership in our diagnostic tests.

Lastly, other things being equal, firms choose to raise funds based on the costs they face. While the prediction about the relative costs of funds in the cross-section is unclear, some firms may opt to use external funds because they face lower costs for external equity than for internal funds. This could occur if internal funds are so scarce that their use would cripple a firm's current operating activities. In such a case, a lower ratio of internal to external equity financing would be associated with higher ERCs, which is a prediction directly opposite to our basic hypothesis. It is thus an empirical question whether the endogeneity of equity funding choices induces a financing pattern cross-sectionally that dominates our prediction of a positive relation between ERCs and the mix of internal to external equity sources. ${ }^{9}$ 
We find that firms with higher ratios of internal to external equity have lower stock betas and thus lower costs of equity capital. This is consistent with the intuition that the cost of external equity is higher than the cost of internal equity. We then test our two hypotheses using annual cross-sectional regressions and data pooled over 11 years. The results provide support for our predictions after controlling for other determinants of ERCs suggested by prior studies (Kormendi and Lipe (1987), Collins and Kothari (1989), Easton and Zmijewski (1989), Lipe (1990), Dhaliwal et al. (1991), Teoh and Wong (1993)): earnings persistence, growth opportunities, riskiness of earnings, auditor quality, and firm size. Moreover, the results are quite robust to the use of both past and prospective measures of the mix of equity funding sources, to an alternative proxy for unexpected earnings, to dividend payout and prior profitability, and to the extent of managerial ownership of shares.

We organize the remainder of the paper as follows. We discuss sample selection procedures and variable definitions in the next section, present the results of the main and diagnostic tests in section 3, and summarize and conclude in the final section.

\section{Empirical Design and Data}

\subsection{Sample Selection}

We include firm-years in our sample that satisfy the following criteria: (a) data for annual earnings per share (excluding extraordinary items and discontinued operations) and the adjustment factor for stock dividends and splits from the 1994 annual Compustat Industrial, Full Coverage, and Research files; (b) stock price and CRSP monthly return data for 75 months ending three months after the end of a given firm-year; (c) data to compute the measure of internal and external equity and the control variables (described below); and (d) no change in fiscal year-end in the current or previous year. ${ }^{10}$ To mitigate the influence of extreme observations, we remove the $1 \%$ largest and smallest values for each 
dependent and independent variable and also remove observations if the absolute value of the ratio of internal to external equity exceeds 10. The selection process yields a sample of 14,955 firm-year observations with year-ends from 1983 through $1993 .{ }^{11}$

\subsection{Basic Empirical Model and Primary Variables}

Our primary empirical analysis is based on the following regression model:

$$
\begin{aligned}
\mathrm{CAR}_{\mathrm{it}}= & \gamma_{0}+\gamma_{1} \mathrm{UX}_{\mathrm{it}}+\gamma_{2} \mathrm{IE}_{\mathrm{it}} \mathrm{UX}_{\mathrm{it}}+\gamma_{3} \mathrm{LEV}_{\mathrm{it}} \mathrm{UX}_{\mathrm{it}}+\gamma_{4} \mathrm{BETA}_{\mathrm{it}} \mathrm{UX}_{\mathrm{it}}+\gamma_{5} \mathrm{PERS}_{\mathrm{it}} \mathrm{UX}_{\mathrm{it}} \\
& +\gamma_{6} \mathrm{HI}_{\mathrm{it}} \mathrm{UX}_{\mathrm{it}}+\gamma_{7} \mathrm{BIG6}_{\mathrm{it}} \mathrm{UX}_{\mathrm{it}}+\gamma_{8} \mathrm{SIZE}_{\mathrm{it}} \mathrm{UX}_{\mathrm{it}}+\varepsilon_{\mathrm{it}}
\end{aligned}
$$

where, for firm $\mathrm{i}$ in year $\mathrm{t}$,

$\mathrm{CAR}_{\mathrm{it}}=$ cumulative abnormal returns;

$\mathrm{UX}_{\mathrm{it}}=$ unexpected earnings;

$\mathrm{IE}_{\mathrm{it}}=$ ratio of internal to external equity;

$\mathrm{LEV}_{\mathrm{it}}=$ leverage;

BETA $_{\text {it }}=$ stock beta;

$\mathrm{PERS}_{\mathrm{it}}=$ indicator variable taking a value of 1 for high earnings persistence, 0 otherwise;

$\mathrm{HI}_{\mathrm{it}}=$ indicator variable taking a value of 1 for high growth opportunities, 0 otherwise;

$\mathrm{BIG6}_{\mathrm{it}}=$ indicator variable taking a value of 1 for a Big 6 client, 0 otherwise;

$\mathrm{SIZE}_{\mathrm{it}}=$ firm size; and

$\varepsilon_{\mathrm{it}}=$ error term.

The dependent variable is cumulative abnormal returns (CARs). We accumulate market model abnormal security returns over the 15 -month period beginning 12 months prior to the fiscal year-end and ending three months after the end of the fiscal year. ${ }^{12}$ Thus, the event period for a firm-year is $[-11$, +3 ], where month 0 is the last month of the fiscal year. We estimate the parameters of the market model using a firm's security return data and the return on the CRSP equally weighted market portfolio 
over the 60 months just prior to the event window. We also assess the sensitivity of the results by using CARs estimated over a 12-month period.

Turning to the independent variables, we define unexpected earnings (UX) as the change in earnings per share deflated by beginning-of-event-year share price. Following Collins and Kothari (1989) and others, we use a random walk model as a proxy for the market's earnings expectation, and thus annual earnings change is our proxy for unexpected earnings. Using more sophisticated ARIMA models requires a relatively long data history to estimate parameter values, and this would reduce the size of the sample significantly. As a diagnostic, we include the level of as well as the change in earnings in the model. Also, for the subset of our sample for which we could obtain $I / B / E / S$ data, we compute unexpected earnings based on analysts' earnings forecasts.

Our primary interest is in the interaction of UX with the mix of equity financing sources. We measure the mix of equity sources as the ratio of internal equity to external equity (IE). The numerator of the IE ratio, internal equity, is the sum of earnings for each year throughout a company's history minus all cash dividend distributions to shareholders. Compustat provides this variable as annual data item \#259 (unadjusted retained earnings). ${ }^{13}$ We define external equity, i.e., the denominator of the IE ratio, as total common shareholder's equity (data item \#60) less internal equity, and we delete any IE ratio having a negative denominator. External equity is our proxy for the cumulative proceeds from issuing common shares less payments for stock repurchases, including treasury stock. ${ }^{14}$

We use the historical cumulative mix of equity funds as a surrogate for a firm's prospective mix of equity funds, which is what influences the prospective discount rate. An alternative surrogate is the actual future mix of equity sources. On the one hand, this surrogate assumes perfect foresight and thus may not reflect current expectations about the future mix of equity sources. On the other hand, it is 
unclear whether the historical mix of funds reflects such expectations since the market may expect a firm to change its mix of equity funds as investment projects are added or completed, or to simply change the funding pattern of its existing projects. We test the robustness of our results based on a firm's historical cumulative mix of equity capital by repeating the primary analysis using a measure of IE that reflects future observations. We compute the future IE ratio as follows. The numerator, future internal equity, is the change in a firm's unadjusted retained earnings from the end of year $t$ to the end of year $t+5$. The denominator, future external equity, is the sum a firm's common and preferred stock issuances over years $t+1$ through $t+5$ net of common and preferred share repurchases. We also consider a variant of this alternative measure that is estimated over years $\mathrm{t}-4$ through $\mathrm{t}^{15}$

\subsection{Variable Definitions: Control Variables}

The remaining independent variables serve as controls for other determinants of ERCs. First, Kormendi and Lipe (1987) find that ERCs are increasing in earnings persistence. Following Ali and Zarowin (1992) and Cheng et al. (1996), we use the ratio of earnings to price $\left(\mathrm{E}_{\mathrm{t}-1} / \mathrm{P}_{\mathrm{t}-1}\right)$ to identify firm-years in which earnings likely are either more transitory or more permanent. Specifically, we rank all firms on Compustat each year by their E/P ratios. Based on these ranks, we place firms with positive earnings in the first nine groups, with an approximately equal number of firms per group, and we place all firms with negative earnings in the tenth group. Our persistence variable, PERS, takes the value of $1(0)$, signifying persistent (transitory) earnings, if the E/P ratio in a firm-year falls in the middle six groups (in the highest two or lowest two groups) of the Compustat population's distribution of E/P values for that year. We also consider a continuous version of the persistence variable. Second, Collins and Kothari (1989) document that ERCs are increasing in growth opportunities. We use the ratio of market value of common equity to book value of common equity (MB) to capture growth prospects. ${ }^{16}$ We classify our 
observations into two groups based on firm-year market to book values relative to the sample median for MB. We assume that a firm belongs in the high growth (low growth) group when its MB measure lies above (falls below) the sample median. Thus, $\mathrm{HI}_{\mathrm{it}}$ equals $1(0)$ if firm $\mathrm{i}$ in year $\mathrm{t}$ belongs in the high (low) growth group.

Third, Collins and Kothari (1989) and Easton and Zmijewski (1989) predict that ERCs are decreasing in the riskiness of earnings. Collins and Kothari find support for that prediction while Easton and Zmijewski do not. Both studies use stock beta to proxy for the riskiness. Bhandari (1988) finds that, after controlling for stock beta, leverage is related positively to average returns, and Dhaliwal et al. (1991) find that leverage is negatively related to ERCs. If estimated betas reliably proxy for true underlying systematic risk, then Bhandari's (1988) and Dhaliwal et al.'s (1991) results are inconsistent with the Capital Asset Pricing Model (CAPM), which predicts that leverage should be captured by stock beta. To minimize the potential effect of any CAPM misspecification, we use stock beta and leverage, together and separately, to proxy for the riskiness of earnings. We obtain a firm's stock beta (BETA) for a given year from the market model estimated to compute its CAR. We measure leverage (LEV) as the ratio of long-term debt to the sum of long-term debt, preferred stock, and common equity. ${ }^{17}$

We also include an indicator variable that equals 1 when a firm's auditor is a Big 6 accounting firm and 0 otherwise. Teoh and Wong (1993) predict ERCs are a positive function of perceived auditor quality. They find support for the prediction using the indicator variable.

Finally, we include firm size as a control that may capture riskiness, the information environment, or other possible factors (Fama and French (1992), Atiase (1985)). ${ }^{18}$ We measure SIZE by taking the natural $\log$ of the market value of equity. 


\subsection{Tests of Hypotheses 1 and 2}

Hypothesis 1 predicts that, other things equal, $\gamma_{2}$ in equation (2) will be positive. That is, there is an incrementally larger ERC as unexpected earnings interacts with larger values of the ratio of internal to external equity.

With regard to Hypothesis 2, we predict that, ceteris paribus, ERCs of high growth firms will be more sensitive to the ratio of internal to external equity than those of low growth firms. To test the hypothesis, we consider the following regression, which augments equation (2) by including the variable $\mathrm{HI}_{\mathrm{it}} \mathrm{IE}_{\mathrm{it}} \mathrm{UX}_{\mathrm{it}}$ :

$$
\begin{aligned}
\mathrm{CAR}_{\mathrm{it}}= & \gamma_{0}+\gamma_{1} \mathrm{UX}_{\mathrm{it}}+\gamma_{2} \mathrm{IE}_{\mathrm{it}} \mathrm{UX}_{\mathrm{it}}+\gamma_{2, \mathrm{H}} \mathrm{HI}_{\mathrm{it}} \mathrm{IE}_{\mathrm{it}} \mathrm{UX}_{\mathrm{it}}+\gamma_{3} \mathrm{LEV}_{\mathrm{it}} \mathrm{UX}_{\mathrm{it}}+\gamma_{4} \mathrm{BETA}_{\mathrm{it}} \mathrm{UX}_{\mathrm{it}} \\
& +\gamma_{5} \mathrm{PERS}_{\mathrm{it}} \mathrm{UX}_{\mathrm{it}}+\gamma_{6} \mathrm{HI}_{\mathrm{it}} \mathrm{UX}_{\mathrm{it}}+\gamma_{7} \mathrm{BIG6}_{\mathrm{it}} \mathrm{UX}_{\mathrm{it}}+\gamma_{8} \mathrm{SIZE}_{\mathrm{it}} \mathrm{UX}_{\mathrm{it}}+\varepsilon_{\mathrm{it}}
\end{aligned}
$$

The coefficient on HI*IE*UX captures the incremental sensitivity of ERCs to IE for high growth firms, and Hypothesis 2 predicts that $\gamma_{2, \mathrm{H}}$ will be greater than 0 . Note that the coefficient on IE*UX in equation (3) reflects the sensitivity of ERCs to IE for low growth firms (rather than the average effect irrespective of the degree of growth, as in equation (2)). Also notice that the sum of coefficients on IE* $\mathrm{UX}$ and $\mathrm{HI} \mathrm{IE}^{*} \mathrm{UX}$ (i.e., $\gamma_{2}+\gamma_{2, \mathrm{H}}$ ) captures the total effect for high growth firms. Because equation (3) is a slightly generalized version of equation (2), one can infer virtually all of the results regarding Hypothesis 1 from equation (3). Hence, for the sake of brevity, we present detailed results only for the estimation of equation (3).

We should also observe a reliably positive ERC, i.e., $\gamma_{1}>0$ (Ball and Brown (1968)), and we expect the following coefficients on the interaction of each control variable and UX: a positive $\gamma_{5}$ reflecting increasing earnings persistence; a positive $\gamma_{6}$ associated with increasing growth opportunities; a 
positive $\gamma_{7}$ capturing higher auditor quality; and indeterminate coefficient signs for leverage, beta, and firm size.

\section{Results}

\subsection{Descriptive Statistics and Correlations}

Table 1 reports summary statistics of the variables (after truncation) for the sample of 14,955 firmyears. As shown in panel A, 15-month CARs average $0.1 \%$ (median $=-1.8 \%$ ), and mean $($ median) unexpected earnings is $1.3 \%(0.7 \%)$ of share price. For descriptive purposes, the remaining variables included in panel A are shown before being multiplied by unexpected earnings. The primary variable of interest, the ratio of internal equity to external equity financing or IE, has a mean (median) of 1.944 (1.174) and ranges from -0.939 to $9.991 .^{19}$ Hence, the average firm has approximately $\$ 1.94$ available in retained earnings for every dollar of equity it has raised by issuing shares. The mean beta in the sample is 1.077 , and the ratio of debt to the sum of debt and equity averages $32.2 \%$. Earnings are persistent in approximately $57 \%$ of firm-years; this is slightly below the roughly $60 \%$ (by construction) for the overall Compustat population. The mean (median) market to book ratio is 1.865 (1.426), and $88.3 \%$ of the sample firms have Big 6 auditors. Finally, there is considerable variation and skewness in the sample distribution of firm size. The mean market value of equity is $\$ 603$ million while the median is $\$ 82$ million. In our regression analyses we use the natural log of firm size.

\section{[Insert Table 1 About Here]}

In order to provide further insight into the IE variable, we correlate it with stock beta. The Pearson product-moment correlation is -0.15 , which is significant in both the pooled sample and when using the means of the 11 annual samples. Hence, there is evidence that firms with higher levels of internal to external equity have lower betas. Notwithstanding possible measurement error in both 
variables, this result suggests that the IE variable is negatively related to the cost of equity capital and that firms with relatively more internal to externally generated equity have lower costs of equity capital.

We report correlations of the regression variables in panel B of Table 1. Correlations based on data pooled over all firms and the entire sample period are shown above the diagonal, and means of correlations based on the data used in the 11 annual cross-sectional regressions appear below the diagonal. Three patterns emerge from the correlation results. First, correlations computed from the pooled data are virtually identical to those based on the means of the annual data sets. Second, unexpected earnings are highly positively correlated with all of the remaining independent variables. In fact, the correlation of each of the other variables with UX is either that variable's highest or second highest correlation. This is not surprising since all of the remaining independent variables interact with UX by construction. Because of the generally high correlations, we compute condition numbers as suggested by Belsley et al. (1980) as part of our analysis to determine whether multicollinearity is a serious problem in our regressions. Third, the pair-wise correlation between IE*UX and every one of the other independent variables is the lowest correlation for each of those variables. This suggests that $\mathrm{IE}^{*} \mathrm{UX}$, the primary variable of interest in this study, is empirically distinct from other determinants of ERCs.

\subsection{Pooled Regression Results}

Panel A of Table 2 presents regression results of pooling all observations across the 1983-93 sample period. We include (but do not report) a dummy intercept for each year (exclusive of 1983) to capture time-varying effects of any omitted variables. We have streamlined the discussion by only reporting results for equation (3) in Tables 2 and 3. To be conservative, we report two-tail significance levels throughout. 
Note first that the mean ERC for the sample is positive $\left(\gamma_{1}=0.787\right)$ and significant $(t=8.11)$. With regard to the control variables, as expected, firms with higher earnings persistence have incrementally larger ERCs $\left(\gamma_{5}=0.841, t=12.67\right)$. Similarly, firms with higher MB ratios, reflective of greater growth opportunities, have larger average ERCs $\left(\gamma_{6}=0.546, t=10.08\right)$, which is consistent with Collins and Kothari (1989). The coefficient on BETA*UX is significant and positive $\left(\gamma_{4}=0.097, \mathrm{t}\right.$ $=1.81)$, while the coefficient on the leverage interaction variable is reliably negative $\left(\gamma_{3}=-0.777, \mathrm{t}=-\right.$ 7.65). The leverage result supports the findings in Dhaliwal et al. (1991). ${ }^{20}$ Finally, neither SIZE nor BIG6 is significant. The absence of a significant coefficient on BIG6*UX is inconsistent with the results in Teoh and Wong (1993).

\section{[Insert Table 2 About Here]}

Turning to the primary hypotheses, the coefficient on $\mathrm{HI}^{*} \mathrm{IE}^{*} \mathrm{UX}\left(\gamma_{2, \mathrm{H}}\right)$ is $0.088(\mathrm{t}=3.14)$. This significant effect is predicted by Hypothesis 2. Thus, firms having greater growth opportunities have ERCs that incrementally are more sensitive to the ratio of internal to external equity financing than the ERCs of low growth firms. The coefficient on IE*UX, which captures the sensitivity of low growth firms' ERCs to IE, is reliably positive $\left(\gamma_{2}=0.080, t=5.11\right)$. Similarly, the sum of coefficients on IE*UX and HI*IE*UX, which reflects the total effect for high growth firms, is also positive $\left(\gamma_{2}+\gamma_{2, \mathrm{H}}=\right.$ $0.080+0.088=0.168)$. These results indicate that that Hypothesis 1 is supported for both high and low growth firms. Moreover, in the estimation results for equation (2), which are not detailed here, the coefficient of $\mathrm{IE}^{*} \mathrm{UX}$ is positive and significant $\left(\gamma_{2}=0.104, \mathrm{t}=7.72\right)$. This confirms the hypothesized relation that firms with higher ratios of internal to external sources of equity have, on average, higher ERCs. 
We investigated the robustness of our results by performing a variety of sensitivity checks. In results not reported here, we find that the empirical support for Hypotheses 1 and 2 is unaffected when (a) the regression model also includes IE, LEV, BETA, PERS, HI, BIG6, and SIZE as independent variables, (b) the level of earnings per share is added to equation (3), (c) a continuous variable is used for persistence (instead of a 0/1 indicator variable), (d) a non-linear relation is allowed for by including the absolute value of UX multiplied by UX as an additional control variable, (e) all the control variables are excluded, ${ }^{21}$ (f) firms with acquisitions in any year during 1975-1994 are excluded for all years, where the acquired firm constitutes at least 5\% of total sales, and (g) absolute values of IE that exceed 2,5 , or 20, respectively, are truncated (as opposed to truncation if $|\mathrm{IE}|>10$ ). In addition, we also find that $\gamma_{2}$ for Hypothesis 1 remains positively significant but $\gamma_{2, \mathrm{H}}$ for Hypothesis 2 becomes insignificant when (a) 12-month (rather than 15-month) CARs are used as the dependent variable (with excess returns accumulated over months -8 through +3 ), (b) negative earnings are excluded, (c) negative values of IE are excluded, and (d) truncation is only based on the largest and smallest $1 \%$ of each independent variable (i.e., no additional observations are deleted based on the absolute value of IE).

We also assessed the sensitivity of the results to a redefinition of external equity (i.e., the denominator of IE). Recall that we define external equity as total stockholders' equity minus internal equity. This means that external equity includes other comprehensive income items, such as gains/losses on foreign currency translations and certain marketable securities, if any. Because many components of other comprehensive income reflect unrealized items, they may not be sources of funds for growth. Hence, we compute an alternative proxy for external equity in which other comprehensive income items are purged. More specifically, the alternative measure of external equity equals total stockholders' equity minus internal equity, minus any cumulative marketable security or foreign currency translation 
adjustments, and plus any recognized minimum pension obligations. ${ }^{22}$ The results (not shown in detail) indicate that $\gamma_{2}=0.097(\mathrm{t}=4.54)$ and $\gamma_{2, \mathrm{H}}=0.144(\mathrm{t}=3.92)$ and thus are qualitatively identical to those reported above.

We also collected data on managers' holdings of shares in their firms from Compact Disclosure over the period 1986-93 to investigate the impact managerial ownership may have on the relation between ERCs and the mix of equity funding sources. When we include manager ownership percentage times unexpected earnings in the regression for the firm-years in our sample for which we have such data $\left(\mathrm{N}=6,994\right.$ or $47 \%$ of the full sample), its coefficient and $\gamma_{2}$ are insignificant while $\gamma_{2, \mathrm{H}}$ is positive and significant at beyond the .01 level. When equation (2) is re-estimated, $\gamma_{2}$ is reliably positive. Finally, we assessed the robustness of the results by estimating a simultaneous equations model that includes equation (3) plus two equations explaining the mix of internal to external equity and the debt to equity ratio. The independent variables for IE and LEV equations include CARs and proxies for growth, expected profitability, a measure of information asymmetry, and managers' share holdings. The basic results are unaffected.

\subsection{Results Based on Annual Regressions}

To the extent that security returns and earnings are cross-sectionally correlated, t-statistics in pooled cross-sectional and time-series regressions will be overstated (Bernard (1987)). One way to address this problem is to estimate annual cross-sectional regressions and test if the mean of the estimated annual coefficients differs from zero. We do this and report the results of estimating 11 annual cross-sectional regressions in panel B of Table 2.

The results are almost identical to those in panel A for the pooled regression analysis. The average coefficient on $\mathrm{HI}^{*} \mathrm{IE} * \mathrm{UX}$ is 0.126 , with a t-statistic of 3.12. This supports Hypothesis 2. In 
addition, the mean coefficient on IE*UX equals 0.074 , with is also significant $(\mathrm{t}=4.83)$, thus supporting Hypothesis 1. With regard to the control variables, panel B shows that the results are highly consistent with the pooled regression results except that the coefficient on BETA*UX becomes insignificant. Hence, the results of both pooled regressions and annual cross-sectional regressions provide consistent and strong support for Hypotheses 1 and $2 .^{23}$

Another approach that has been suggested to overcome the potential cross-sectional bias in tstatistics from pooled regressions is to use firm-specific regressions to test the hypothesis (Teets and Wasley (1996)). We implement this approach for the subset of firms in our sample having the necessary data by calculating each sample firm's ERC over a ten (or 11) year period and each firm's average IE over the same period. We then compute the Pearson correlation between the estimated firm-specific ERCs and IEs. We find the correlation is 0.19 (p-value $=.0001$ ), which supports our basic hypothesis that high internal funding firms have lower discount rates and thus higher ERCs.

\subsection{Consideration of Alternative Explanations for the Results}

We evaluate several alternative explanations for the results in this section. First, while financial slack reflects the availability of internal funds, it may also have a cost related to Jensen's (1986) free cash flow hypothesis. In particular, managers may choose to retain funds in their firms for personal consumption. The free cash flow problem is seen as most likely to occur in mature firms. In a test of the free cash flow hypothesis, Kallapur (1994) provides evidence of a positive relation between dividend payout rates and ERCs for a sample of large and long-surviving NYSE companies. ${ }^{24}$ To the extent that mature firms are also low growth firms that have low dividend payouts, then the free cash flow problem is potentially an alternative explanation of the results for Hypothesis 2. However, the free cash flow explanation is inconsistent with the results of Hypothesis 1 where we make no distinction between high 
and low growth firms. Moreover, in the analyses of Hypothesis 2 , the coefficient on $\mathrm{IE}_{\mathrm{it}} * \mathrm{UX}_{\mathrm{it}}$, which captures the impact for low growth firms, is reliably positive both in the pooled regression results in panel A of Table 2 and in the annual regressions in panel B. That is, Hypothesis 1 is supported for low growth firms as well as for high growth firms, which is inconsistent with the free cash flow explanation.

Second, it might be argued that our measure of internal to external equity is correlated with firms' dividend payout rates, and that we simply are detecting the empirical regularity that Kallapur (1994) has previously documented. To investigate this possibility, we re-estimate equation (3) after including the interaction of the dividend payout ratio and earnings change as an additional explanatory variable. ${ }^{25}$ Hence, we essentially run a horse race between the dividend payout and IE interaction variables to see which variable best explains ERCs. The results (not shown) indicate that the dividend payout ratio variable is insignificant and our primary results remain unchanged. Further, we also include average ROA*UX in the model (where average ROA is return on assets averaged over years $\mathrm{t}-3$ through $\mathrm{t}-1$ and proxies for prior profitability) to examine whether the prior profitability rather than the mix of equity financing is the factor that explains the magnitude of ERCs. The coefficient on the ROA interaction variable is reliably positive, the coefficient on dividend payout* $\mathrm{UX}$ is insignificant, and most importantly, both $\gamma_{2}$ and $\gamma_{2, \mathrm{H}}$ are reliably positive.

\subsection{Diagnostic Tests Using Analysts' Earnings Forecasts}

To assess the sensitivity of the results to the measure of unexpected earnings, we compute unexpected earnings using the consensus of financial analysts' forecasts as an alternative to the change in earnings. We collect forecast data for all sample firm-year observations that are available from $I / B / E / S$ over the 11-year sample period. We require that forecasts be of annual primary earnings per share and be made nine months prior to the end of a firm's fiscal year. ${ }^{26}$ We adjust for stock splits and dividends using 
Compustat adjustment figures. Unexpected earnings is the difference between primary earnings per share obtained from Compustat and the median consensus $I / B / E / S$ earnings forecast. We deflate by beginning-of-year share price, and drop the $1 \%$ highest and lowest $I / B / E / S$-based unexpected earnings to minimize problems with extreme values. The selection procedure yields a sample of 7,746 firm-years (or approximately $52 \%$ of the full sample). The mean (median) of the $I / B / E / S$-based unexpected earnings is $-4.7 \%(-1.5 \%){ }^{27}$

In Table 3, panel A, we present the results for pooled regressions. Both hypotheses are supported. The HI*IE*UX coefficient, $\gamma_{2, \mathrm{H}}$, is 0.272 , which is reliably positive $(\mathrm{t}=5.04)$. Further, $\gamma_{2}$ $=0.122$, which is also significant $(\mathrm{t}=4.16)$, and thus Hypothesis 1 is supported for both low growth and high growth firms. ${ }^{28}$ In addition, the ERC is reliably positive $\left(\gamma_{1}=0.954, \mathrm{t}=3.50\right)$. Also, as was the case with the results reported earlier, the coefficient on leverage is negative and significant, and the coefficients on beat, persistence, and high growth are positive and significant. However, the coefficients on the BIG6 and firm size variables are significant and negative. Hence, the results for these control variables are sensitive to the use of an alternative measure of unexpected earnings (and/or a smaller sample). However, the results of the main hypothesis tests are robust to the use of $I / B / E / S$-based unexpected earnings.

\section{[Insert Table 3 About Here]}

\subsection{Diagnostics Using Alternative Measures of the Mix of Internal to External Equity Financing}

As a final set of diagnostic tests, we replace the historical measure of the mix of equity funds with two alternative measures of IE. The first alternative uses a future measure of IE, computed over years $\mathrm{t}+1$ through $t+5$, to proxy for a firm's prospective mix of equity capital. ${ }^{29}$ The results using this proxy are 
based on a smaller sample ( $\mathrm{N}=2,682$ or $18 \%$ of the full sample) since we require each firm-year observation to have five years of non-missing data to compute its future IE value.

Panel B of Table 3 displays the pooled regression results of estimating equation (3) with the future IE proxy. There is a reliably positive coefficient on $\mathrm{HI}^{*} \mathrm{IE}^{*} \mathrm{UX}\left(\gamma_{2, \mathrm{H}}=0.088, \mathrm{t}=2.31\right)$, which supports Hypothesis 2. With regard to Hypothesis 1, the coefficient for low growth firms does not differ from zero $(0.020, t=0.91)$, although the coefficient on $\mathrm{IE}^{*} \mathrm{UX}$ when equation (2) is estimated is significant $\left(\gamma_{2}=0.048, \mathrm{t}=2.74\right)$. Additionally, the $\mathrm{ERC}$ and the persistence and growth opportunities coefficients are again reliably positive and leverage is reliably negative. Hence, the basic results are not

sensitive to this alternative proxy for the prospective measure of the mix of equity financing. ${ }^{30}$ Finally, we repeat this analysis by computing IE based on a second alternative definition; specifically, we use the immediate past five years' of data (i.e., years t-4 through t) instead of the immediate five subsequent years to proxy for the firm's prospective mix of equity funding. The results (not shown), which are also based on a small sample, support Hypothesis 1 when estimating equation (2) and are significant for low growth firms but not for high growth firms (and thus do not support Hypothesis 2) when estimating equation (3).

\section{Conclusion}

We investigate whether the source of equity capital has an impact on the relation between abnormal security returns and unexpected earnings. Firms exhibit a strong preference for internal sources of funds over external financing. Intuitive and conceptually-based explanations of that phenomenon, which recognize transactions costs and asymmetric manager/investor information about investment plans, suggest that the cost of internal funds is lower than the cost of external equity. Indeed, we find a negative correlation between stock beta and the ratio of retained earnings to contributed capital. We 
postulate that the mix of firms' sources of equity capital will affect the costs of equity capital the market uses to discount firms' unexpected earnings. Specifically, the cost of equity capital should decrease as firms use a higher proportion of internal equity relative to external equity, and, in turn, the ERCs of such firms should increase. Furthermore, ERCs of high growth firms should be more sensitive to the ratio of internal to external equity than those of low growth firms, given the greater manager/investor information asymmetries that arise in the presence of the larger portfolio of positive NPV projects that high growth firms wish to finance. We test these predictions using pooled and annual cross-sectional regressions and including controls for other determinants of ERCs. The results support our predictions and are generally robust to a wide range of diagnostic checks.

According to the "pecking order" theory of Myers (1984) and Myers and Majluf (1984), issuing shares has the highest manager/investor information asymmetry cost, internal funding has the lowest information asymmetry cost, and issuing risky debt falls in the middle. However, debt also reflects financial risk and has its own agency cost (e.g., Myers (1977)). While we capture some of these costs in our leverage and beta interaction variables, future empirical research might develop better proxies and examine the relation of all sources of financing and ERCs.

Our results should also be of interest to theoreticians. We document empirical regularities that support the existence of a determinant of ERCs that has previously not been hypothesized. Our empirical analyses include controls for other ERC determinants that appear in the prior literature and also sensitivity tests to guard against the possibility of correlated omitted variables or measurement error in the included variables. Nevertheless, extant theory of the determinants of earnings response coefficients has not yet advanced to the point of allowing imperfect markets and thus the transactions 
costs and the asymmetric manager/investor information sets that underlie our predictions. Our empirical results thus may provide theoreticians with some valuable information as they develop their models. 
Table 1. Descriptive statistics and correlations.

Panel A: Descriptive statistics ( $N=14,955$ firm-years over the period 1983-93)

\begin{tabular}{l|lllll}
\hline Variable & Mean & Std dev & Min & Median & Max \\
\hline CAR $_{\text {it }}$ & 0.001 & 0.497 & -1.442 & -0.018 & 1.858 \\
$\mathrm{UX}_{\text {it }} / \mathrm{P}_{\text {it-1 }}$ & 0.013 & 0.160 & -0.697 & 0.007 & 1.213 \\
$\mathrm{IE}_{\text {it }}$ & 1.944 & 2.374 & -0.939 & 1.174 & 9.991 \\
$\mathrm{LEV}_{\text {it }}$ & 0.322 & 0.209 & 0.000 & 0.308 & 0.895 \\
$\mathrm{BETA}_{\text {it }}$ & 1.077 & 0.425 & -0.002 & 1.059 & 2.356 \\
$\mathrm{PERS}_{\text {it }}$ & 0.572 & 0.495 & 0 & 1 & 1 \\
$\mathrm{MB}_{\text {it }}$ & 1.865 & 1.573 & 0.297 & 1.426 & 17.058 \\
$\mathrm{BIG6}_{\text {it }}$ & 0.883 & 0.322 & 0 & 1 & 1 \\
$\mathrm{SIZE}_{\text {it }}(\$$ millions $)$ & 603 & 1,513 & 1 & 82 & 14,200 \\
\hline
\end{tabular}

Variable definitions: for firm $\mathrm{i}$ at time $\mathrm{t}, \mathrm{CAR}_{\mathrm{it}}=$ cumulative abnormal returns over the 15 -month period ending three months after the end of a firm's fiscal year-end; $\mathrm{UX}_{\mathrm{it}}=$ unexpected earnings per share divided by beginning-of-event-year share price, where UX is the change in earnings per share before extraordinary items and discontinued operations; $\mathrm{IE}_{\mathrm{it}}=$ ratio of internal equity to external equity, measured as the sum of all of a firm's annual earnings less all dividends (Compustat annual data item \#259) divided by total common shareholders' equity (data item \#60) minus internal equity; $\mathrm{LEV}_{\mathrm{it}}=$ leverage, measured as the ratio of total long-term debt (data items \#9 and \#44) to the sum of long-term debt, preferred stock (data item \#130), and common shareholders' equity; $\mathrm{BETA}_{\mathrm{it}}=$ stock beta from the market model estimated over the 60 months prior to the event year that yields the estimated parameters used to compute $\mathrm{CAR}_{\mathrm{it}}$; $\mathrm{PERS}_{\mathrm{it}}=$ an indicator variable equaling $1(0)$ for high earnings persistence (otherwise), where earnings are persistent (transitory) if $\mathrm{E}_{\mathrm{t}-1} / \mathrm{P}_{\mathrm{it}-1}$ falls in the middle six groups (in the highest two or lowest two groups) in that year's ranking of the Compustat population's $\mathrm{E} / \mathrm{P}$ values; $\mathrm{MB}_{\mathrm{it}}=$ market value of equity to book value of equity; $\mathrm{BIG}_{\mathrm{it}}=$ an indicator variable equaling 1 (0) for a Big 6 client (otherwise); $\mathrm{SIZE}_{\mathrm{it}}=$ firm size, measured as the market value of equity; the natural log of SIZE is used in the regression analyses. The descriptive statistics are based on data after truncation. We remove the $1 \%$ largest and smallest values for each continuous variable. We also remove observations if the absolute value of IE exceeds 10. 
Panel B: Pearson correlations between independent variables (14,955 pooled firm-year observations above the diagonal; means of 11 annual sets of data below the diagonal)

\begin{tabular}{lccccccccc}
\hline Variable & CAR & UX & IE*UX & LEV*UX & BETA*UX & PERS*UX & HI*UX & BIG6*UX & SIZE*UX \\
\hline CAR & 1.000 & 0.326 & 0.178 & 0.250 & 0.310 & 0.235 & 0.242 & 0.309 & 0.308 \\
UX & 0.327 & 1.000 & 0.365 & 0.864 & 0.927 & 0.407 & 0.563 & 0.934 & 0.882 \\
IE*UX & 0.182 & 0.360 & 1.000 & 0.264 & 0.276 & 0.259 & 0.075 & 0.343 & 0.417 \\
LR*UX & 0.250 & 0.866 & 0.256 & 1.000 & 0.798 & 0.317 & 0.547 & 0.811 & 0.766 \\
BETA*UX & 0.311 & 0.928 & 0.271 & 0.801 & 1.000 & 0.382 & 0.566 & 0.884 & 0.846 \\
PERS*UX & 0.237 & 0.402 & 0.257 & 0.311 & 0.377 & 1.000 & 0.236 & 0.385 & 0.421 \\
HI*UX & 0.240 & 0.554 & 0.074 & 0.544 & 0.560 & 0.230 & 1.000 & 0.533 & 0.550 \\
BIG*UX & 0.309 & 0.932 & 0.338 & 0.811 & 0.884 & 0.382 & 0.526 & 1.000 & 0.867 \\
SIZE*UX & 0.307 & 0.882 & 0.413 & 0.767 & 0.847 & 0.416 & 0.536 & 0.868 & 1.000 \\
\hline
\end{tabular}

Variable definitions: CAR = cumulative abnormal returns over the 15-month period ending three months after the end of a firm's fiscal year-end; $\mathrm{UX}=$ unexpected earnings per share divided by beginning-of-event-year share price, where UX is the change in earnings per share before extraordinary items and discontinued operations; IE* $\mathrm{UX}=$ ratio of internal equity to external equity times UX, where IE is measured as the sum of all of a firm's annual earnings less all dividends (Compustat annual data item \#259) divided by total common shareholders' equity (data item \#60) minus internal equity; LEV*UX = leverage times UX, where LEV is measured as the ratio of total long-term debt (data items \#9 and \#44) to the sum of long-term debt, preferred stock (data item \#130), and common shareholders' equity; BETA*UX = stock beta times UX, where beta is from the market model estimated over the 60 months prior to the event year that yields the estimated parameters used to compute cumulative abnormal returns; PERS*UX = an indicator variable times UX, where PERS equals 1 (0) for high earnings persistence (otherwise) and earnings are persistent (transitory) if $\mathrm{E}_{\mathrm{it}-1} / \mathrm{P}_{\mathrm{it}-1}$ falls in the middle six groups (in the highest two or lowest two groups) in that year's ranking of the Compustat population's E/P values; $\mathrm{HI} * \mathrm{UX}=$ an indicator variable times $\mathrm{UX}$, where $\mathrm{HI}$ equals 1 (0) if the market value of equity to book value of equity is above the sample median (otherwise); BIG6*UX = an indicator variable times UX, where BIG6 equals 1 (0) for a Big 6 client (otherwise); $\mathrm{SIZE}^{*} \mathrm{UX}=$ firm size times UX, where SIZE is measured as the natural log of the market value of equity. The data are after truncation. We remove the $1 \%$ largest and smallest values for each continuous variable. We also remove observations if the absolute value of IE exceeds 10. 
Table 2. Primary results.

Panel A: Pooled regressions $(N=14,955$ firm-years $)$

$\mathrm{CAR}_{\mathrm{it}}=\gamma_{0}+\gamma_{1} \mathrm{UX}_{\mathrm{it}}+\gamma_{2} \mathrm{IE}_{\mathrm{it}} \mathrm{UX}_{\mathrm{it}}+\gamma_{2, \mathrm{H}} \mathrm{HI}_{\mathrm{it}} \mathrm{IE}_{\mathrm{it}} \mathrm{UX}_{\mathrm{it}}+\gamma_{3} \mathrm{LEV}_{\mathrm{it}} \mathrm{UX}_{\mathrm{it}}+\gamma_{4} \mathrm{BETA}_{\mathrm{it}} \mathrm{UX}_{\mathrm{it}}+\gamma_{5} \mathrm{PERS}_{\mathrm{it}} \mathrm{UX}_{\mathrm{it}}+\gamma_{6} \mathrm{HI}_{\mathrm{it}} \mathrm{UX}_{\mathrm{it}}+\gamma_{7} \mathrm{BIG6}_{\mathrm{it}} \mathrm{UX}_{\mathrm{it}}+\gamma_{8} \mathrm{SIZE}_{\mathrm{it}} \mathrm{UX}_{\mathrm{it}}+\varepsilon_{\mathrm{it}}$

\begin{tabular}{lllllllllll}
\hline & $\mathrm{UX}$ & IE*UX & HI*IE*UX & LEV*UX & BETA*UX & PERS*UX & HI*UX & BIG6*UX & SIZE*UX & Adj. R ${ }^{2}$ \\
\hline Coefficient & 0.787 & 0.080 & 0.088 & -0.777 & 0.097 & 0.841 & 0.546 & 0.081 & -0.005 \\
$(\mathrm{t}-$ statistic) & $(8.11)^{* * *}$ & $(5.11)^{* * *}$ & $(3.14)^{* * *}$ & $(-7.65)^{* * *}$ & $(1.81)^{*}$ & $(12.67)^{* * *}$ & $(10.08)^{* * *}$ & $(1.11)$ & $(-0.34)$ \\
\hline
\end{tabular}

Panel B: Annual regressions (1983-93)

$\mathrm{CAR}_{\mathrm{i}}=\gamma_{0}+\gamma_{1} \mathrm{UX}_{\mathrm{i}}+\gamma_{2} \mathrm{IE}_{\mathrm{i}} \mathrm{UX}_{\mathrm{i}}+\gamma_{2, \mathrm{H}} \mathrm{HI}_{\mathrm{i}} \mathrm{IE}_{\mathrm{i}} \mathrm{UX}_{\mathrm{i}}+\gamma_{3} \mathrm{LEV}_{\mathrm{i}} \mathrm{UX}_{\mathrm{i}}+\gamma_{4} \mathrm{BETA}_{\mathrm{i}} \mathrm{UX}_{\mathrm{i}}+\gamma_{5} \mathrm{PERS}_{\mathrm{i}} \mathrm{UX}_{\mathrm{i}}+\gamma_{6} \mathrm{HI}_{\mathrm{i}} \mathrm{UX}_{\mathrm{i}}+\gamma_{7} \mathrm{BIG6}_{\mathrm{i}} \mathrm{UX}_{\mathrm{i}}+\gamma_{8} \mathrm{SIZE}_{\mathrm{i}} \mathrm{UX}_{\mathrm{i}}+\varepsilon_{\mathrm{i}}$

\begin{tabular}{cccccccccccc}
\hline & Intercept & UX & IE*UX & HI*IE*UX & LEV*UX & BETA*UX & PERS*UX & HI*UX & BIG6*UX & SIZE*UX & adj. R ${ }^{2}$ \\
\hline Coefficient & -0.013 & 0.847 & 0.074 & 0.126 & -0.812 & 0.117 & 0.834 & 0.512 & 0.055 & -0.007 & 0.139 \\
(t-statistic) & $(-1.26)$ & $(5.65)^{* * *}$ & $(4.83)^{* * *}$ & $(3.12)^{* *}$ & $(-4.53)^{* * *}$ & $(1.81)$ & $(8.16)^{* * *}$ & $(6.48)^{* * *}$ & $(0.55)$ & $(-0.31)$ & \\
\hline
\end{tabular}

$\mathrm{HI}^{*} \mathrm{IE}^{*} \mathrm{UX}=$ ratio of internal equity to external equity times UX times 1 (0) if firm i year t belongs to the high (low) growth group, where high (low) growth is defined as MB above (below) the sample median. See Table 1, panel B, for definitions of the remaining variables.

$\varepsilon_{\text {it }}=$ error term.

Significance levels (two-tail): $*=.10 ; * *=.05 ; * * *=.01$. 
Table 3. Diagnostic results.

Panel A: Pooled regressions with I/B/E/S-based unexpected earnings $(N=7,746$ firm-years $)$

$\mathrm{CAR}_{\mathrm{it}}=\gamma_{0}+\gamma_{1} \mathrm{UX}_{\mathrm{it}}+\gamma_{2} \mathrm{IE}_{\mathrm{it}} \mathrm{UX}_{\mathrm{it}}+\gamma_{2, \mathrm{H}} \mathrm{HI}_{\mathrm{it}} \mathrm{IE}_{\mathrm{it}} \mathrm{UX}_{\mathrm{it}}+\gamma_{3} \mathrm{LEV}_{\mathrm{it}} \mathrm{UX}_{\mathrm{it}}+\gamma_{4} \mathrm{BETA}_{\mathrm{it}} \mathrm{UX}_{\mathrm{it}}+\gamma_{5} \mathrm{PERS}_{\mathrm{it}} \mathrm{UX}_{\mathrm{it}}+\gamma_{6} \mathrm{HI}_{\mathrm{it}} \mathrm{UX}_{\mathrm{it}}+\gamma_{7} \mathrm{BIG6}_{\mathrm{it}} \mathrm{UX}_{\mathrm{it}}+\gamma_{8} \mathrm{SIZE}_{\mathrm{it}} \mathrm{UX}_{\mathrm{it}}+\varepsilon_{\mathrm{it}}(3)$

\begin{tabular}{lllllllllll}
\hline & $\mathrm{UX}$ & IE*UX & HI*IE*UX & LEV*UX & BETA*UX & PERS*UX & HI*UX & BIG6*UX & SIZE*UX & adj. R \\
\hline Coefficient & 0.954 & 0.122 & 0.272 & -0.337 & 0.202 & 1.050 & 0.174 & -0.482 & -0.064 \\
$(\mathrm{t}-$ statistic) & $(3.50)^{* * *}$ & $(4.16)^{* * *}$ & $(5.04)^{* * *}$ & $(-1.83)^{*}$ & $(1.83)^{*}$ & $(11.21)^{* * *}$ & $(1.71)^{*}$ & $(-2.56)^{* *}$ & $(-2.17)^{* *}$ & \\
\hline
\end{tabular}

Panel B: Pooled regressions with future actual realizations of internal and external equity financing $(N=2,682$ firm-years $)$

$\mathrm{CAR}_{\mathrm{it}}=\gamma_{0}+\gamma_{1} \mathrm{UX}_{\mathrm{it}}+\gamma_{2} \mathrm{IE}_{\mathrm{it}} \mathrm{UX}_{\mathrm{it}}+\gamma_{2, \mathrm{H}} \mathrm{HI}_{\mathrm{it}} \mathrm{IE}_{\mathrm{it}} \mathrm{UX}_{\mathrm{it}}+\gamma_{3} \mathrm{LEV}_{\mathrm{it}} \mathrm{UX}_{\mathrm{it}}+\gamma_{4} \mathrm{BETA}_{\mathrm{it}} \mathrm{UX}_{\mathrm{it}}+\gamma_{5} \mathrm{PERS}_{\mathrm{it}} \mathrm{UX}_{\mathrm{it}}+\gamma_{6} \mathrm{HI}_{\mathrm{it}} \mathrm{UX}_{\mathrm{it}}+\gamma_{7} \mathrm{BIG6}_{\mathrm{it}} \mathrm{UX}_{\mathrm{it}}+\gamma_{8} \mathrm{SIZE}_{\mathrm{it}} \mathrm{UX}_{\mathrm{it}}+\varepsilon_{\mathrm{it}}$

\begin{tabular}{lllllllllll}
\hline & $\mathrm{UX}$ & IE*UX & HI*IE*UX & LEV*UX & BETA*UX & PERS*UX & HI*UX & BIG6*UX & SIZE*UX & adj. R \\
\hline Coefficient & 1.111 & 0.020 & 0.088 & -0.927 & 0.053 & 1.009 & 0.489 & -0.062 & 0.007 & 0.152 \\
$(\mathrm{t}-$ statistic $)$ & $(4.06)^{* * *}$ & $(0.91)$ & $(2.31)^{* *}$ & $(-3.73)^{* * *}$ & $(0.43)$ & $(6.75)^{* * *}$ & $(4.09)^{* * *}$ & $(-0.27)$ & $(0.19)$ & \\
\hline
\end{tabular}

In panel $\mathrm{A}, \mathrm{UX}_{\mathrm{it}}$, unexpected earnings, is computed using earnings forecasts from $I / B / E / S$.

In panel $\mathrm{B}, \mathrm{IE}_{\mathrm{it}}$ is the ratio of future internal equity to external equity, where the numerator is the change in Compustat data item \#259 (unadjusted retained earnings) from year-end $t$ to year-end $t+5$, and the denominator is the sum of data item \#108 (sale of common and preferred stock) over the years $t+1$ through $t+5$ less data item \#115 (purchase of common and preferred stock) over the years $t+1$ through $t+5$ less the change in data item \#130 (preferred stock) from year-end to year-end $\mathrm{t}+5$.

See Table 1, panel B, for definitions of the remaining variables.

$\varepsilon_{\text {it }}=$ error term.

Significance levels (two-tail): $*=.10 ; * *=05 ; * * *=.01$. 


\section{References}

Ali, A, and P. Zarowin. 1992. "The Role of Earnings Levels in Annual Earnings-Returns Studies." Journal of Accounting Research 30 (Autumn): 286-296.

Atiase, R. 1985. "Predisclosure Information, Firm Capitalization, and Security Price Behavior Around Earnings Announcements." Journal of Accounting Research 23 (Spring): 21-35.

Ball, R. and P. Brown. 1986. "An Empirical Investigation of Accounting Income Numbers," Journal of Accounting Research 6 (Spring): 159-178.

Barth, M. E., R. Kasznik, M. F. McNichols. 1999. "Analyst Coverage and Intangible Assets," Working Paper, Stanford University.

Belsley, D., E. Kuh, and R. Welsch. 1980. Regression Diagnostics, Identifying Influential Data And Sources of Collinearity. New York: Wiley.

Bernard, V. 1987. "Cross-sectional dependence and problems in inference in market-based accounting research." Journal of Accounting Research 25 (Spring): 1-48.

Bhandari, L. 1988. "Debt/Equity Ratio and Expected Common Stock Returns: Empirical Evidence." Journal of Finance 43 (June): 507-528.

Brealey, R.A. and S.C. Myers. 1984. Principles of Corporate Finance. New York: McGraw-Hill, $2^{\text {nd }}$ edition.

Brealey, R.A. and S.C. Myers. 1996. Principles of Corporate Finance. New York: McGraw-Hill, $5^{\text {th }}$ edition.).

Brown, P., G. Foster, and E. Noreen. 1985. Security Analyst Multi-year Earnings Forecasts and the Capital Market. Sarasota, FL: American Accounting Association.

Chaney, P. and D. Jeter. 1992. "The Effect of Size on the Magnitude of Long-window Earnings Response Coefficients." Contemporary Accounting Research 8 (Spring): 540-560.

Cheng, G.S.A., C-S. Liu, and T. Schaefer. 1996. "Earnings Performance and the Incremental Information Content from Operations, Journal of Accounting Research 34 (Spring): 173-181.

Collins, D. and S. Kothari. 1989. "An Analysis of Intertemporal and Cross-sectional Determinants of Earnings Response Coefficients." Journal of Accounting and Economics 11 (July): 143-81.

Darrough, M. and N. Stoughton. 1990. "Financial Disclosure Policy In An Entry Game." Journal of Accounting and Economics 12 (January): 219-243. 
Dhaliwal, D., K. Lee, and N. Fargher. 1991. "The Association Between Unexpected Earnings and Abnormal Security Returns in the Presence of Financial Leverage." Contemporary Accounting Research 8 (Fall): 20-41.

Dhaliwal, D., K.R. Subramanyam, and R. Trezevant. 1999. "Is Comprehensive Income Superior to Net Income as a Measure of Firm performance?" Journal of Accounting and Economics 26 (January): 43-67.

Easton, P. and M. Zmijewski. 1989. "Cross-sectional Variation in the Stock Market Response to Accounting Earnings Announcements," Journal of Accounting and Economics 11 (July): 11742.

Fama, E. and K. French. 1992. "The Cross-section of Expected Stock Returns," Journal of Finance 47 (June): 427-65.

Feltham, G. and J Ohlson. 1995. "Valuation and Clean Surplus Accounting for Operating and Financial Activities." Contemporary Accounting Research 11 (1995): 689-731.

James, C. and P. Wier. 1988. "Are Bank Loans Different?: Some Evidence for the Stock Market." Journal of Applied Corporate Finance (1988): 46-54.

Jensen, M. 1986. "The Agency Cost of Free Cash Flow, Corporate Finance and Takeovers." American Economic Review 76 (May): 323-329.

Kallapur, S. 1994. "Dividend Payout Ratios as Determinants of Earnings Response Coefficients." Journal of Accounting and Economics 17 (May): 359-375.

Kallapur, S. and M. Trombley. 1999. "The Association Between Investment Opportunity Set Proxies and Realized Growth." Journal of Business Finance and Accounting 26 (April/May): 505519.

Kormendi, R., and R. Lipe. 1987. "Earnings Innovations, Earnings Persistence and Stock Returns." Journal of Business 60 (July): 323-45.

Lipe, R. 1990. "The Relations Between Stock Returns and Accounting Earnings Given Alternative Information." The Accounting Review 65 (January): 49-71.

Modigliani, F. and M. Miller. 1958. "The Cost of Capital, Corporation Finance and the Theory of Investment." American Economic Review 48 (June): 261-297.

Myers, S. 1977. "Determinants of Corporate Borrowing." Journal of Financial Economics 5 (November): 147-175. 
Myers, S. 1984. "The Capital Structure Puzzle." Journal of Finance 34 (July): 575-92.

Myers S. and N. Majluf. 1984 "Corporate Financing and Investment Decisions When Firms have Information that Investors Do not Have." Journal of Financial Economics 13 (June): 87-221.

Pinegar, J.M. and L. Wilbricht. 1989. "What Managers Think of Capital Structure Theory: A Survey." Financial Management 18 (Winter): 82-91.

Smith, C. 1977. "Substitute Methods for Raising Additional Capital: Rights Offerings versus Underwritten Issues" Journal of Financial Economics 5 (December): 273-307.

Smith, C. 1986. "Raising Capital: Theory and Evidence." Midland Corporate Finance Journal (Spring).

Teets, W. and C. Wasley. 1996. "Estimating Earnings Response Coefficients: Pooled versus Firmspecific Models." Journal of Accounting and Economics 21 (June): 279-295.

Teoh, S. and T. Wong. 1993. "Perceived Auditor Quality and the Earnings Response Coefficient." The Accounting Review 68 (April): 346-66.

Weston, J.F. and E. Brigham. 1982. Essentials of Managerial Finance. Chicago, Dryden Press, $6^{\text {th }}$ edition. 


\section{Endnotes}

${ }^{1}$ For example, based on Federal Reserve data for a 20-year period, Brealey and Myers (1984, chp. 14) document that internally generated funds accounted for between $46 \%$ and $76 \%$ of funds used for capital expenditures and investments in operating assets. In a subsequent 12-year period the range was $62 \%$ to $90 \%$ (Brealey and Myers (1996, chp. 14)).

${ }^{2}$ This information asymmetry can exist because managers cannot fully disclose their information about investment projects without placing their firms at a competitive disadvantage (Darrough and Stoughton (1990)).

${ }^{3}$ However, financial slack may exacerbate a free cash flow (i.e., agency) problem (Jensen (1986)). We consider this below.

${ }^{4}$ Thus, the determinants of ERCs rely on perfect markets, and the rigorous generalization of ERCs under asymmetric information has yet to be worked out. Feltham and Ohlson (1995) provide the framework that is probably the most complete and consistent with contemporary valuation theory. While the theoretical determinants of ERCs can be rigorously examined within their framework, the use of discounting in it is derived from the no arbitrage property of a perfect market setting. Generalizations of this setting that incorporate asymmetric information have not been derived.

${ }^{5}$ For example, Collins and Kothari (1989) and Easton and Zmijewski (1989) define the discount rate using the expected rate of return on equity from the Capital Asset Pricing Model, which assumes a perfect capital market.

${ }^{6}$ Algebraic rearrangement of equation (1) yields: $\mathrm{r}=[\mathrm{E} /(\mathrm{I}+\mathrm{E})] \times\left[\left\{(\mathrm{I} / \mathrm{E}) \times \mathrm{r}_{\mathrm{i}}\right\}+\mathrm{r}_{\mathrm{e}}\right]$, and $\mathrm{r}=[1 /(\mathrm{K}$ $+1)] \times\left[\left(K \times r_{i}\right)+r_{e}\right]$ where $K=I / E$. Since we maintain that $r_{e}$ and $r_{i}$ are parameters and $r_{e}$ is greater than $r_{i}$, it follows that $\partial r / \partial K=-\left[\left(r_{e}-r_{i}\right) /(1+K)^{2}\right]<0$.

${ }^{7}$ A larger gap between the costs of internal and external equity implies that the weighted-average cost of equity capital (i.e., the discount rate) for high growth firms will be more sensitive to the ratios of internal to external equity than the discount rates of low growth firms. That is, given that $\partial \mathrm{r} / \partial \mathrm{K}=-\left[\left(\mathrm{r}_{\mathrm{e}}-\right.\right.$ $\left.\left.\mathrm{r}_{\mathrm{i}}\right) /(1+\mathrm{K})^{2}\right]<0$ from Endnote $6, \partial \mathrm{r} / \partial \mathrm{K}$ should be more negative for high growth firms relative to low growth firms, and consequently $\partial(\mathrm{ERC}) / \partial \mathrm{K}$ should be greater for high growth firms.

${ }^{8}$ In the case of closely held firms, as distinct from widely held firms, we would expect less bias and noise in reported earnings numbers, which would lead to a prediction of higher ERCs.

${ }^{9}$ As a diagnostic to our primary empirical analysis, we employ a simultaneous equations approach in which cumulative abnormal returns, a firm's mix of internal to external equity, and leverage are dependent variables in interrelated regressions. However, the data demands for independent variables in these models, especially manager holdings of shares, sharply reduce our sample size. 
${ }^{10}$ Regarding criterion (b), we assume the annual report is released by the end of the third month after the end of a fiscal year, and thus we compute returns through that month. Criterion (d) ensures that the change in earnings is the difference between the current 12-month earnings and the previous 12-month earnings.

${ }^{11}$ We begin in 1983 since it is the first full year that Compustat reports information on unadjusted retained earnings (item \# 259), which we use below in our measure of internal to external equity. We end with fiscal 1993 to allow for a diagnostic test that uses an alternative measure of internal to external equity that is based on data from the subsequent five years.

${ }^{12}$ See Chaney and Jeter (1992) for a discussion of short-window and long-window studies.

${ }^{13}$ Our discussions with a Compustat technical support person indicate that Compustat's retained earnings variable (data item \#36) equals the sum of data items \#230, \#231, \#238, and \#259. That is, retained earnings is the sum of retained earnings-cumulative translation adjustment, retained earningsother adjustments (e.g., for stock dividends and stock splits effected as stock dividends), marketable securities adjustment (for unrealized gains/losses on available-for-sale securities under SFAS No. 115 or on long-term investments under SFAS No. 12), and retained earnings-unadjusted (for cumulative earnings less cumulative cash dividends).

${ }^{14}$ As a diagnostic, we also define the denominator of IE as total stockholder's equity minus internal equity and minus other comprehensive income items (e.g., gains/losses on foreign currency translations and certain marketable securities).

15 The need for five years of data sharply reduces the sample sizes available to analyze these alternative proxies for the prospective mix of equity funding sources.

${ }^{16}$ Realized growth can be viewed for the unobservable investment opportunity set (IOS) of the firm, and it provides a benchmark against which IOS proxy variables can be compared. Results from such a comparison indicate that many of the variables from earlier studies, including book to market measures and capital expenditure ratios, are consistently correlated with subsequent realized growth (see Kallapur and Trombley (1999)). In addition, R\&D intensity and E/P ratios do not exhibit any consistent association with subsequent growth, suggesting that they may not be valid IOS proxies. Kallapur and Trombley (1999) also find that the incremental contribution of other variables over the book to market ratio is low.

${ }^{17}$ Long-term debt is the sum of Compustat data item \#44 (debt due in one year) and data item \#9 (debt due in more than one year). Preferred stock is data item \#130.

${ }^{18}$ Fama and French (1992) find that stock beta has no explanatory power for average returns after controlling for size. Atiase (1985) argues that private information production and dissemination are 
increasing in firm size and provides supporting evidence. Thus, on average, there is greater information asymmetry for smaller firms vis-à-vis larger firms.

${ }^{19}$ Negative values of IE in the sample occur only when the numerator, unadjusted retained earnings, is negative.

20 The correlation between BETA*UX and $\mathrm{LEV} * \mathrm{UX}$ is approximately 0.80 . The results are qualitatively identical when BETA*UX is dropped from the model, and when LEV*UX is dropped.

${ }^{21}$ Finding that the results are unaffected when CAR is regressed only on UX and IE*UX in equation (2) and only on UX, IE*UX, and $\mathrm{HI}^{*} \mathrm{IE}^{*} \mathrm{UX}$ in equation (3) suggests that it is unlikely that spurious results are being induced by any problems due to possible multicollinearity or correlated omitted variables (assuming no important variables are omitted from equation (3)).

22 That is, Compustat data items \#60-\#259-\#238-\#230+(\#298-\#297), if \#298 > \#297; \#60-\#259\#238-\#230, otherwise (see Dhaliwal et al. (1999)). Note that for years prior to 1986, it is \#60-\#259\#238-\#230 since minimum pension liability data were not reported prior to SFAS No. 87.

${ }^{23}$ We compute condition numbers for all the regressions. In no case does any condition number exceed 20, which indicates there is no evidence of serious multicollinearity problems in the data (see Belsley et al. (1980)).

${ }^{24}$ Kallapur (1994) examines 112 NYSE firms having data over the 1951-86 period and median 1986 sales of $\$ 3.8$ billion.

${ }^{25}$ The dividend payout ratio is defined as dividends per share (Compustat data item \#26) divided by earnings per share (data item \#54). Values below (above) zero (one) are winsorized to zero (one).

${ }^{26}$ We use forecasts made nine months prior to the end of a firm's fiscal year since they are expected to impound information from the prior year's earnings.

${ }^{27}$ Brown et al. (1985) find that mean forecast errors based on $I / B / E / S$ forecasts range from $-5.3 \%$ to $5.7 \%$ for forecasts made nine to eleven months prior to the announcement of earnings.

${ }^{28} \gamma_{2}=0.192(t=7.47)$ when equation (2) is estimated.

${ }^{29}$ For this alternative measure, internal financing is measured as the change in Compustat data item \#259 (unadjusted retained earnings) from year-end t to year-end $t+5$. External financing is measured as the sum of data item \#108 (sale of common and preferred stock) over the years $t+1$ through $t+5$ less data item \#115 (purchase of common and preferred stock) over the years $t+1$ through $t+5$ less the change in data item \#130 (preferred stock) from year-end t to year-end $t+5$. The results remain 
qualitatively unchanged (but less significant) when the future IE variable is computed over three years instead of five years.

${ }^{30}$ In this analysis, we have excluded cases of negative external equity financing. That is, we require that the denominator of IE, which is sales of common and preferred stock net of repurchases over the five years, be positive since it is hard to interpret IE when the denominator is negative. As a further diagnostic, we exclude both negative numerators and denominators. The results, which are based on $\mathrm{N}$ $=1,581$ observations, are qualitatively the same except that the test of Hypothesis 1 is significant at only the .15 level (two-tail) when equation (2) is estimated. 